\title{
LA LIBERTAD \\ DE IMPRENTA COMO PREMISA DE LA PRIMERA CONSTITUCIÓN RACIONAL-NORMATIVA ESPAÑOLA: LA CONSTITUCIÓN DE CÁDIZ DE 1812
}

ANTONIO MAGDALENO ALEGRÍA 
SUMARIO

1. EL CONTEXTO DEL RECONOCIMIENTO DE LA LIBERTAD DE IMPRENTA. 2. LOS FUNDAMENTOS DE LA LIBERTAD DE IMPRENTA. 3. CONTENIDO Y LÍMITES DE LA LIBERTAD DE IMPRENTA. 4. LA LIBERTAD DE IMPRENTA COMO PREMISA DE LA ELABORACIÓN DE LA PRIMERA CONSTITUCIÓN RACIONAL-NORMATIVA EN ESPAÑA. 5. LA LIBERTAD DE IMPRENTA COMO PIEZA CLAVE DE LAS RECIÉN CREADAS INSTITUCIONES LIBERALES. 


\title{
LA LIBERTAD \\ DE IMPRENTA COMO PREMISA \\ DE LA PRIMERA CONSTITUCIÓN RACIONAL-NORMATIVA ESPAÑOLA: LA CONSTITUCIÓN DE CÁDIZ DE 1812
}

\author{
ANTONIO MAGDALENO ALEGRÍA \\ Profesor contratado Doctor de Derecho Constitucional \\ Universidad de Cantabria
}

\section{EL CONTEXTO DEL RECONOCIMIENTO DE LA LIBERTAD DE IMPRENTA}

En España, la libertad de imprenta surgió y se reconoció en un contexto muy peculiar. Concretamente, el inicio de la Guerra de la Independencia generó la desaparición de la censura previa y posibilitó de facto la libertad de imprenta. En efecto, la contienda frente al invasor francés y el vacío de poder regio colapsaron el sistema de censura previa que, desde su instauración mediante la Pragmática de los Reyes Católicos, actuaba en el seno del país ${ }^{1}$. Pese a los esfuerzos

1 De hecho, el sistema de censura y el celo en la importación de libros había aumentado considerablemente pocos años antes al objeto de evitar que las ideas de la revolución francesa se propagaran por España. Concretamente Carlos IV, mediante el Decreto de 4 de febrero de 1791, ordenó el cese inmediato de todos los periódicos, a excepción del Diario de Madrid, y prohibió la importación de libros sediciosos. No obstante, como recuerda FIESTAS LOZA, «los franceses residentes en España, los vendedores ambulantes, los comerciantes y los impresores lograron burlar las citadas medidas, utilizando toda suerte de estratagemas para ello». Véase FIESTAS LOZA, A.: «La libertad de imprenta en las dos primeras etapas del liberalismo español», Anuario de Historia del Derecho español, Tomo LIX, 1989, pág. 354. Asimismo, sobre la cuestión, entre otros, véanse 
de la Junta Central, tras el estallido de la Guerra de la Independencia, escritos y periódicos de todo tipo ${ }^{2}$, muchos de ellos con claro contenido ideológico liberal, circularon libremente por el país sin ningún tipo de cortapisa eficaz ${ }^{3}$. De hecho, la libertad de imprenta se reveló como un instrumento valioso para fomentar el patriotismo y la lucha contra los franceses ${ }^{4}$.

Dejando al margen el Estatuto de Bayona, el primer reconocimiento positivo de la libertad de imprenta se realizó mediante el Decreto IX, de 10 de noviembre de 1810 , sobre la libertad política de imprenta. Lo cierto es que antes

LA PARRA LÓPEZ, E.: La libertad de prensa en las Cortes de Cádiz, Valencia, Nau Llibres, 1984, pág. 20 y ss., CHECA GODOY, A.: La prensa española durante la Guerra de la Independencia, Cádiz, Quórum editores, 2009, pág. 19 y ss.; ALMUIÑA, C.: «Opinión pública y revolución liberal», Cuadernos de Historia Contemporánea, Vol. XXIV, 2002, pág. 82 y ss.

2 Durante los primeros momentos de la Guerra de la Independencia la prensa se dividió fundamentalmente en dos bandos, a saber, la prensa afrancesada y la prensa patriota. Posteriormente esta división es sustituida por la de servil y liberal. Sobre la tipología de de los periódicos durante el periodo de la guerra de independencia, entre otros, véanse CHECA GODOY, A.: La prensa española durante la Guerra de la Independencia, ob.cit., pág. 33 y ss. y Véase GIL NOVALES, A.: Prensa, guerra y revolución. Los periódicos españoles durante la Guerra de la Independencia, Madrid, CESIC, 2009, pág. 30 y ss.

3 En referencia a la cuestión aludida supra, el Semanario Patriótico publicó lo siguiente: «si alguno hubiera dicho a principios de octubre pasado, que antes de un año teníamos libertad de escribir sobre la reforma del gobierno, planes de constitución, examen y reducción del poder, y que apenas se publicaría escrito alguno en España que no se dirigiese a estos objetivos importantes; hubiera sido tenido por un hombre falto de seso, a quien tal vez se privara de su libertad por la que profetizaba a los otros. Sin embargo así es, y la extraña variedad de sucesos por donde hemos llegado a este punto, acaso no admirará tanto a la posteridad, como al acierto y osadía con que se enuncian y examinan los principios políticos en una Nación, a quien toda Europa, creía por la larga y continua opresión, ajena enteramente de semejantes investigaciones, y sumida en la más profunda ignorancia». Véase Semanario Patriótico, núm. IV, de 22 de septiembre de 1808 , pág. 62.

4 La prensa patriótica de la época trató de desprestigiar a Napoleón y su hermano José mediante el recurso a las medias verdades, la sátira e incluso al insulto. Asimismo, muchos periódicos nacionales utilizaron la mentira como un elemento de estrategia militar y de motivación a los combatientes. Sobre la prensa patriótica durante el periodo de la Guerra de la Independencia, entre otros, véase GIL NOVALES, A.: Prensa, guerra y revolución. Los periódicos españoles durante la Guerra de la Independencia, ob. cit., pág. 25 y ss.

Para el bando francés, la prensa también fue un elemento muy importante en su estrategia bélica. De hecho, la prensa fue concebida como un formidable instrumento de propaganda. Así, por ejemplo, la prensa francesa recordará e incluso exagerará las victorias francesas y la figura infalible de su Emperador. Sobre la utilización de la prensa como método propagandístico por Napoleón, entre otros, véanse PIZARROSO QUINTERO, A.: «Prensa y propaganda bélica 1808-1814», Cuadernos dieciochistas, núm. 8, 2007, págs. 203 y ss., y ALMUNIA, C.: «Opinión pública y revolución liberal», Cuadernos de Historia Contemporánea, Vol. 24, 2002, págs. 98 y ss. 
de la convocatoria y puesta en funcionamiento de las Cortes, algunos autores ya reclamaron a la Junta Central, eso sí, con distintos matices, la necesidad de proceder al reconocimiento de la libertad de imprenta 5 .

Que el reconocimiento de la libertad de imprenta fuese reclamado a la Junta Central y que, precisamente, fuera una de las primeras normas estudiadas y aprobadas por las Cortes, incluso antes que la propia Constitución, no puede ser considerado casual. Como se analizará a lo largo del presente estudio, los constituyentes liberales entendieron que la citada libertad pública era una pieza esencial para el diseño y posterior consolidación del sistema constitucional en España. Así, la elaboración de la Constitución de Cádiz de 1812, que puede ser calificada de racional-normativa ${ }^{6}$, al tener su origen en el libre contraste de las ideas, exigió el reconocimiento previo de la libertad de imprenta. Asimismo, la vigencia efectiva de la Constitución como norma reguladora del Estado hacía necesaria su aceptación social, por ser considerada como legítima y expresar el código de valores presente en la sociedad, ocupando la libertad de imprenta una función esencial al respecto ${ }^{7}$.

En el presente trabajo se abordará, desde una perspectiva constitucional, el papel que debía desempeñar la libertad de imprenta durante la elaboración y vigencia de la primera Constitución racional-normativa en España. Al objeto

5 Fueron varios los autores que dirigieron escritos a la Junta Central, entre los que se resaltarán los elaborados por Calvo de Rozas, Álvaro Florez Estrada y José Pablo Valiente. Sobre la cuestión, entre otros, véanse ARTOLA GALLEGO, M.: Los orígenes de la España contemporánea, Madrid, Instituto de Estudios Políticos, Vol. I, 1978, págs. 280 y ss.; FERNÁNDEZ SEGADO, F.: «La libertad de imprenta en las Cortes de Cádiz», Revista de Estudios Políticos, núm. 124, 2004, pág. 31 y ss., ÁLVAREZ JUNCO, J. y DE LA FUENTE MONGE, G.: El nacimiento del periodismo político. La libertad de imprenta en las Cortes de Cádiz (1808-1814), Madrid, Ediciones APM, 2009, pág. 46 y ss.; FERNÁNDEZ SARASOLA, «Opinión pública y "libertades de expresión” en el constitucionalismo español», Historia Constitucional (revista electrónica), núm. 7, 2006, pág. 163 y ss.; GÓMEZ-REINO Y CARNOTA, E.: Aproximación histórica al derecho de la imprenta y de la prensa (1480-1966), Madrid, Instituto de Estudios Administrativos, 1977, pág. 90 y ss.

6 Siguiendo la definición elaborada por el profesor GARCÍA-PELAYO, el concepto racional-normativo «concibe la Constitución como un complejo normativo establecido de una sola vez y en el que de una manera total, exhaustiva y sistemática se establecen las funciones fundamentales del Estado y se regulan los órganos, el ámbito de sus competencias y las relaciones entre ellos». Se trata de un diseño político basado en la racionalidad, esto es, se partió de la creencia en que era posible estructurar toda la vida del Estado con arreglo a unas normas predeterminadas y predeterminadoras. Véase GARCÍA-PELAYO, M.: Derecho Constitucional comparado, Madrid, Alianza, 1999, pág. 34 y ss.

7 En este sentido, Florez Estrada mantuvo que «sin libertad de imprenta no pueden difundirse las luces, y sin ellas ni puede haber reforma útil y estable, ni los españoles podrán ser jamás libres ni felices». Véase FLOREZ ESTRADA, A.: En defensa de las Cortes, Madrid, Ciencia Nueva, 1967, pág. 149. 
de realizar la citada labor se enunciará, en primer lugar, los principales motivos que esgrimieron los constituyentes gaditanos para justificar el reconocimiento de la libertad de imprenta en España. En segundo lugar, se delimitará la citada libertad pública, esto es, se determinará su haz de facultades. Posteriormente, se analizarán sus limitaciones pues, como se observará, la libertad de imprenta, como el resto de libertades, no se reconoció en términos absolutos, sino que se establecieron restricciones al objeto de preservar los derechos de los demás y determinados bienes esenciales para la estabilidad del nuevo régimen constitucional. Finalmente se estudiará la necesidad de reconocer la libertad de imprenta con carácter previo a la elaboración de la Constitución, así como su papel en la implantación de la norma fundamental.

\section{LOS FUNDAMENTOS DE LA LIBERTAD DE IMPRENTA}

A los pocos días de constituirse las Cortes gaditanas se decidió crear una comisión al objeto de elaborar un proyecto sobre la libertad de imprenta ${ }^{8}$. La relativa celeridad con la que se discutió y aprobó el Decreto de imprenta hizo patente la importancia del asunto para el sector liberal representado en las Cortes ${ }^{9}$.

En el preámbulo del Decreto IX, de 10 de noviembre de 1810, se sintetizaron los principales motivos que llevaron a las Cortes al reconocimiento de la libertad de imprenta, ahora bien, lo cierto es que también existieron otros fines que estaban directamente relacionados con las circunstancias especiales por las que atravesaba el país en aquel momento como, por ejemplo, posibilitar la llamada a la resistencia y el levantamiento contra el invasor francés ${ }^{10}$.

8 Concretamente formaron parte de dicha Comisión once diputados, a saber: Benito Ramón Hermida, Antonio Oliveros, Diego Muñoz Torrero, Agustín Argüelles, Evaristo Pérez de Castro, Pedro Ceballos Guerra de la Vega, Antonio Capmany, José María Couto, Juan Nicasio Gallego, Tomás del Monte y Esteban Palacios. Véase DSCGE, de 27 de septiembre de 1810, pág. 12.

9 Así, por ejemplo, ya en la sesión de 30 de septiembre de 1810, el diputado Argüelles propuso a las Cortes que se abordara el estudio de la libertad política de imprenta, dado que se trataba de un preliminar necesario para la salvación de la patria. Véanse, entre otros, El Conciso, núm. XX, de 30 de septiembre de 1810, pág. 94 y ss.

El proyecto sobre la libertad de imprenta se presentó el día 14 de octubre de 1810. Durante ese día y los siguientes se produjeron intervenciones a favor y en contra del mismo. Entre las primeras destacaron los discursos de Argüelles, Torrero, Mexía, Oliveros y Luxan y, en referencia a las segundas, sobresalieron las intervenciones de Tenreiro, Morales Gallego, Llaneras y Ros. Para conocer las aludidas intervenciones, entre otras publicaciones periódicas de la época, se puede consultar El Conciso, núm. XXIX, de 18 de octubre de 1810, págs. 133 y ss., y números siguientes.

10 A modo de ejemplo, el Semanario Patriótico destacó el papel de la prensa durante la Guerra de la Independencia del siguiente modo: la «absoluta necesidad de dar a este resorte 
Pues bien, en cuanto a los fundamentos explicitados, como idea general, se puede afirmar que los constituyentes gaditanos concibieron la libertad de imprenta no sólo como un derecho individual que posibilitaba el libre desarrollo de la personalidad, sino que también era un derecho que desempeñaba importantes funciones sociales. En concreto, desde esta última perspectiva, las Cortes esgrimieron tres fundamentos distintos y, en consecuencia, se analizarán de manera separada:

En primer lugar, el preámbulo del Decreto enunció que la libertad de imprenta constituye «un freno de la arbitrariedad de los que gobiernan». Sin lugar a duda, se trata de una cuestión vital para el funcionamiento del régimen constitucional que se pretendía instaurar en España. El Decreto I, de 24 de septiembre de 1810, consagró, entre otras cuestiones, la soberanía nacional y el principio de separación de poderes, cuestiones que posteriormente también se plasmaron en la Constitución de $1812^{11}$. En consecuencia, la soberanía ya no residía en el Monarca sino en la Nación y, precisamente, los constituyentes gaditanos eran los representantes de la misma. Pues bien, la libertad de imprenta supuso la posibilidad de que la ciudadanía fiscalizara y controlara el ejercicio del poder político. Si las Cortes tenían la potestad de elaborar las leyes y de controlar la acción del Gobierno, la ciudadanía, mediante la prensa y la posibilidad de publicar sus escritos, podía controlar y ejercer la censura social frente al Gobierno y las propias Cortes y, de esta manera, evitar cualquier abuso en el ejercicio del poder. Además, la libertad de imprenta estaba llamada a cumplir una importante función pacificadora, pues garantizar su libre ejercicio posibilitaba un cauce pacífico para dirimir las divergencias políticas y sociales y, por ende, esta libertad pública podía contribuir a asegurar la estabilidad social y política ${ }^{12}$. Dicho de otro modo, la libertad de imprenta constituía una válvula de escape social, un medio

moral cuanta elasticidad sea posible, y para ello no hay mejores meatos que los que proporciona la imprenta en los papeles periódicos; destinados por su naturaleza a excitar, sostener y guiar la opinión pública. Así lo han conocido las Provincias de España en cuyas capitales luego se formó la resolución general de sacudir el yugo abominable que nos querían imponer, al instante salieron las Gacetas y los Diarios para exaltar el patriotismo, y comunicar luces y noticias». Véase prospecto del Semanario Patriótico de 1808.

11 Sobre las discusiones en torno a la cuestión de la soberanía en las Cortes de Cádiz, entre otros, véase FERNÁNDEZ SARASOLA, I.: La Constitución de Cádiz: origen, contenido y proyección internacional, Madrid, CEPC, 2011, págs. 145 y ss.

12 La referida idea fue esgrimida durante la tramitación de la libertad de imprenta. Así, el diputado Muñoz Torrero enlazó la libertad de expresión con la paz civil, pues el derecho del pueblo a expresar libremente sus opiniones y quejas políticas sobre los actos de sus gobernantes legítimos es la forma pacífica de defender su libertad. De no reconocerse esta libertad, 
legítimo de crítica alternativo a la insurrección civil como modo de defender las ideas.

En segundo lugar, consideraron que la libertad de imprenta es «el único camino para llevar al conocimiento de la opinión pública». La libertad de imprenta potencialmente facilitaba la existencia de una opinión pública libre. Además, y no por ello menos importante, la posibilidad de difundir libre y públicamente ideas, opiniones e informaciones significó la garantía de un vehículo de comunicación o interrelación entre la ciudadanía y las Cortes. Así, mediante la garantía de la libertad de imprenta, las Cortes podían conocer las ideas de los ciudadanos sobre su actuación o en torno a las necesidades políticas que debían ser atendidas por la Cámara. En consecuencia, las Cortes debían, cuanto menos, tener muy presente la guía de la opinión pública a la hora de adoptar sus decisiones y elaborar las leyes de la Nación.

En tercer y último lugar, según el aludido preámbulo, la posibilidad de poder difundir ideas e informaciones sin censura previa constituía un medio para ilustrar a la población en general. Se trata de una cuestión que procede directamente del pensamiento ilustrado que atribuía gran parte de los males de la sociedad a la falta de instrucción de la población y, asimismo, a la inexistencia de un debate público, libre y racional, donde las ideas debían competir unas con otras hasta que vencieran las mejores para el colectivo. La imprenta se desveló como un instrumento muy valioso para propagar las luces entre la población, para dar noticia de los nuevos descubrimientos o dar cuenta de los acontecimientos políticos y sociales ${ }^{13}$. En este sentido, no fue una casualidad que la libertad de imprenta fuese incluida en el título IX de la Constitución de 1812 bajo la rúbrica «de la instrucción pública ${ }^{14} »$.

el pueblo sólo podrían acudir a la insurrección. Véase El Español, núm. 8, 30 de noviembre de 1810 , págs. 158 y ss.

13 En el preámbulo de la Constitución de Cádiz de 1812, elaborado por ARGÜELLES, se plasmó esta idea con meridiana claridad, de la siguiente manera: «nada contribuye más directamente a la ilustración y adelantamiento general de las Naciones y la conservación de su independencia que la libertad de publicar todas las ideas y pensamientos que puedan ser útiles y beneficiosos para los súbditos del Estado, la libertad de imprenta, verdadero vehículo de las luces, debe formar parte de la ley fundamental de la monarquía, si los españoles desean sencillamente ser libres y dichosos».

14 Sobre esta cuestión, resulta interesante la postura de Jovellanos. El citado autor tuvo sus serias dudas, durante su época en la Junta Central, sobre la oportunidad de reconocer la libertad de imprenta, al menos, teniendo en cuenta las características de la población española de aquel momento. Concretamente consideró que la libertad de imprenta sin la previa instrucción de la población generaría una opinión pública irracional. Sobre la cuestión, véase FERNÁNDEZ 


\section{CONTENIDO Y LÍMITES DE LA LIBERTAD DE IMPRENTA}

El reconocimiento gaditano de la libertad de imprenta implicó la posibilidad de difundir pública y libremente ideas, pensamientos, sentimientos e informaciones sin necesidad de obtener previamente ninguna autorización ${ }^{15}$. Consecuentemente se trató de un derecho civil, que básicamente suponía la ausencia de intromisiones de cualquier poder público o eclesiástico en el proceso de comunicación pública. Sin embargo, a diferencia de las regulaciones de otros Estados liberales, el Decreto de imprenta excluyó de su ámbito de protección a aquellos escritos que versaran sobre cuestiones religiosas ${ }^{16}$. Concretamente, el artículo 6 del Decreto estableció que: «todos los escritos sobre materias de religión quedan sujetos a la previa censura de los Ordinarios eclesiásticos, según

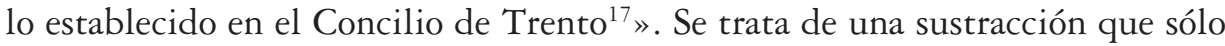
se puede comprender teniendo en cuenta las adscripciones ideológicas de los diputados constituyentes ${ }^{18}$, pues se trató de una concesión de los liberales frente a los absolutistas en aras a obtener su ansiada libertad de expresión a través de

SARASOLA, I.: Poder y libertad: los orígenes de la responsabilidad del ejecutivo en España (1808-1823), Madrid, CEPC, 2001, pág. 322 y ss.

15 Obviamente, como se desprende del propio título y del contenido del Decreto de imprenta, la libertad de imprenta no supone el reconocimiento de la libertad de expresión tal y como lo hace la Constitución vigente en España, sino que se circunscribió a su modalidad de manifestación escrita, en el convencimiento de que a través de los escritos la transmisión de las ideas se realiza de una manera más meditada y, por ende, con mayor posibilidad de ilustrar a la Nación.

16 El diputado Mexía, consciente de la enorme transcendencia de la cuestión, trató infructuosamente de que la abolición de la censura previa alcanzara a todo tipo de escritos y, por tanto, también a los escritos religiosos; cuestión que fue rechazada por la gran mayoría de diputados representados en las Cortes. Sobre la cuestión, véase El Conciso, núm. XXXIII, de 6 de octubre de 1810 , págs. 149 y ss.

17 A pesar de que durante la tramitación del Decreto de imprenta el inquisidor Riesco propuso que se añadiera un artículo donde se aludiera expresamente a que el Decreto de imprenta no perjudicaba a las atribuciones del Santo Oficio en la materia, lo cierto es que la citada norma guardó silencio sobre la cuestión. Años más tarde, mediante el Decreto CXXIII, 22 de febrero de 1813, las Cortes promulgaron la incompatibilidad de la Inquisición con la Constitución de 1812 y, por ende, su abolición. La abolición del Santo Oficio y su sustitución por los Tribunales protectores de la Fe desborda el objeto del presente trabajo. Sobre la cuestión, entre otros, véanse ESCUDERO, J.A.: «Las Cortes de Cádiz y la supresión de la Inquisición», en ESCUDERO J.A. (Dir.): Cortes y Constitución de Cádiz, Vol. II, Madrid, Espasa, 2011, págs. 285 y ss. y DAFOUR, G.: «¿Cuándo fue abolida la Inquisición en España», Cuadernos de Ilustración y Romanticismo, núm. 13, 1995, págs. 93 y ss.

18 Sobre las tendencias políticas y perfil social de los diputados que intervinieron durante el debate, véase ÁLVAREZ JUNCO, J. y DE LA FUENTE MONGE, G.: El nacimiento del periodismo político. La libertad de imprenta en las Cortes de Cádiz (1808-1814), ob. cit. pág. 103 y ss. 
los escritos en materia política ${ }^{19}$. A pesar de la referida transacción parlamentaria, la indeterminación normativa sobre cuáles eran los escritos religiosos generó una enorme inseguridad jurídica y, por tanto, importantes problemas en la aplicación del Decreto. No obstante, el Decreto supuso un tímido avance respecto a la regulación del Antiguo Régimen, pues estableció que el Ordinario tenía la obligación de revisar y escuchar las razones del autor en el caso de que tuviera la intención de negar la licencia. Si finalmente el Ordinario no otorgaba la licencia, el interesado podía acudir ante la Junta Suprema adjuntando los motivos esgrimidos para no autorizar la publicación. En el caso de que la Junta Suprema disintiera del criterio del Ordinario, le reenviaría la obra para que reconsiderara su postura, «si le pareciere». Finalmente, si el Ordinario ratificaba su posición, el Decreto se limitó a enunciar la posibilidad de recursos posteriores, si bien no los especificó ${ }^{20}$.

Por otro lado, en cuanto a los sujetos titulares de la libertad de imprenta, el Decreto reconoció este derecho a «todos los cuerpos y personas particulares de cualquiera condición y estado que sean ${ }^{21} »$. En consecuencia, y a priori, todos los individuos podían difundir libremente sus ideas políticas. Ahora bien, desde la perspectiva liberal, los individuos deben procurarse los medios materiales para el

Lo cierto es que, como afirma CASTRO ALFÍN, resulta sorprendente la suspicacia y recelo del sector servil en referencia a la libertad de imprenta, pues en esa época histórica el público lector constituía una reducida parte de la población, «casi tan reducido como el de los ciudadanos con plenitud de derechos políticos que reconocía el sufragio censitario», cuestión que, según el citado autor, «parece situar la confrontación política en el plano básicamente idealista o abstracto, en el encuentro de principios y conceptos». Véase CASTRO ALFÍN, D.: Los males de la imprenta. Política y libertad de prensa en una sociedad dual, Madrid, CIS, 1998, pág. 28.

19 Al respecto Argüelles trató de justificar la referida decisión en la situación vivida en las Cortes de la siguiente manera: «el deseo de conciliar los ánimos hizo que se renunciase a una parte esencial del objeto al que se aspiraba. De cuantas cosas habían contribuido a la ruina de la Nación, ninguna era mayor ni más directa que el exorbitante influjo del clero. Por tanto, no había reforma que más urgiese que la de moderarlo a lo menos, restringiendo las usurpaciones que había hecho, en varias épocas de la Monarquía, sobre el estado civil de la sociedad (...) La comisión consideró prudente limitar en el proyecto de ley a sólo opiniones políticas la libertad de publicar los escritos sin censura previa. En esta limitación se hacía un doloroso sacrificio de la libertad de imprenta en obsequio del clero exclusivamente». Véase ARGÜELLES, A.: Examen histórico de la reforma de la Constitución española, Bilbao, Junta General del Principado de Asturias, 2002, pág. 223 y ss.

20 Véanse artículos 19 y 20 del Decreto de Imprenta.

21 Sobre la polémica en torno a la titularidad de la libertad de imprenta, entre otros, véase FERNÁNDEZ SEGADO, F.: «La libertad de imprenta en las Cortes de Cádiz», ob. cit., pág. 43 y ss., ÁLVAREZ JUNCO, J. y DE LA FUENTE MONGE, G.: El nacimiento del periodismo político. La libertad de imprenta en las Cortes de Cádiz (1808-1814), ob. cit., pág. 158 y ss. 
ejercicio de las libertades públicas. Por ende, sólo aquellos sujetos que disponían de recursos suficientes para costear la impresión de panfletos, periódicos, etc., podían ejercer esta libertad efectivamente ${ }^{22}$. Por tanto, a pesar de reconocerse la titularidad de la libertad de imprenta en términos sumamente amplios, sólo un reducido grupo de la población podía expresarse efectivamente ${ }^{23}$. El acceso al ideal libre mercado de las ideas quedaba restringido de facto, que no de iure. Como también sucede en la actualidad, durante el periodo de la Guerra de la Independencia los propietarios de los periódicos determinaron qué cuestiones eran debatidas y cómo se debían llevar a cabo tales controversias ${ }^{24}$.

En cuanto a la cuestión de los límites de la libertad de imprenta, cabe recordar que el liberalismo no concibió las libertades públicas de manera absoluta. Así pues, el Decreto estableció diversas limitaciones a la libertad de imprenta a lo largo de su articulado. De hecho, los principales valedores de la libertad de imprenta siempre expresaron en sus proyectos ante la Junta Central y, posteriormente, durante sus intervenciones parlamentarias, la necesidad de establecer relaciones a la libertad de imprenta. Sin lugar a duda, salvada la cuestión de los escritos religiosos, durante la discusión sobre los límites de la libertad de imprenta se hizo plausible la confrontación entre los sectores liberales y absolutistas presentes en las Cortes $^{25}$. En relación con las concretas restricciones de la libertad de imprenta, se puede afirmar que, en síntesis, respondieron a dos

22 Como afirma CHECA GODOY, la prensa durante el periodo de la Guerra de la Independencia resultó un negocio incierto, pues se trató de una actividad que generaba altos gastos (destinados esencialmente a la redacción, impresión y correos), los suscriptores fueron relativamente escasos y contenían escasa publicidad. Véase CHECA GODOY, A.: La prensa española durante la Guerra de la Independencia, ob. cit., pág. 81 y ss. La circunstancia anterior y la existencia de un alto número de periódicos, conducen a la conclusión de que probablemente la rentabilidad que se buscó mediante la prensa era más política que económica.

23 En referencia a los concretos promotores de los periódicos durante el periodo de la Guerra de la Independencia, CHECA GODOY alude a que fueron escasos los periódicos promovidos por los militares, siendo, por el contrario, mucho más numerosos los promovidos por escritores, políticos (sobre todo diputados de las Cortes gaditanas), el clero o los impresores. Como se observa, se trata de sectores sociales con importantes recursos económicos y amplia instrucción. Véase CHECA GODOY, A.: La prensa española durante la Guerra de la Independencia, ob. cit., pág. 63.

24 Sobre las ideas y actitudes de la prensa durante el referido periódico histórico, véase, entre otros, CHECA GODOY, A.: La prensa española durante la Guerra de la Independencia, ob. cit., pág. 47 y ss.

25 En este sentido, como sintetiza ÁLVAREZ CORA, los diputados contrarios a la libertad de imprenta en vez de prestar atención en la cuestión de la abolición de la censura previa, concentraron su estrategia en las cuestiones relacionadas con la protección frente al abuso de la libertad de imprenta. Véase ÁLVAREZ CORA, E.: «Libertad, abuso y delito de imprenta en las Cortes de Cádiz», Anuario de Historia del Derecho español, Tomo LXXXI, núm. 81, 2011, pág. 496. 
objetos distintos: de un lado, proteger los derechos de los demás, esencialmente el derecho al honor, y, de otro, preservar determinados elementos esenciales para la estabilidad del régimen liberal (la soberanía e independencia de la Nación, las Cortes, etc.). En este sentido, fueron considerados delictivos los libelos infamatorios y los escritos calumniosos que, respectivamente, castigaban los escritos que denigraban a otras personas y los escritos que imputaban falsamente la comisión de un delito. Respecto a los segundos, se castigaron los escritos subversivos contra las leyes fundamentales de la monarquía, los licenciosos y los contrarios a la decencia pública y las buenas costumbres. La tipificación de los escritos sediciosos supuso, cuanto menos, una aparente contradicción con los postulados liberales pues, en cierto modo, suponía un acercamiento a la reglamentación del Antiguo Régimen, dado que se castigaban los escritos que atacaban los elementos esenciales en los que se basaban sus reformas políticas. Máxime teniendo en cuenta que su proyecto constitucional se basaba en la racionalidad y, por ende, no existía otra forma de saber si el nuevo orden político iba a asegurar la justicia y la felicidad de los individuos que poder discutirlo libre y públicamente, incluso con sus detractores ${ }^{26}$. La citada contradicción se justificó por el interés

26 Lo cierto es que de las intervenciones de varios diputados se infiere que se está ante un límite absoluto. En este sentido, se puede destacar que el diputado Guridi y Alcocer presentó un papel, finalmente no admitido, donde se estableció una triple clasificación de los impresos castigados por el Decreto de imprenta: «Los inductivos a delitos, como robos, asesinatos (...) deberán ser castigados por el delito a que contribuyen, según el grado en que contribuyen. Los subversivos del Estado o de las leyes deben igualmente castigarse con las penas a que ellos les corresponde. La dificultad consiste en distinguir cuándo provocan o inducen a desobedecer una ley, y cuando son una crítica de ella. Lo primero nunca es lícito, y sí lo segundo; pero ¡cuán arduo es asignar el lindero entre uno y otro! Mi dictamen es que sobre las leyes fundamentales en que se establecen las primeras y principales bases del Estado (y las que deben designarse expresamente) no pueda admitirse ni crítica, porque hasta ella es subversiva. ¿Cómo podrá, por ejemplo, criticarse de injusta una ley que establece la monarquía, sin inducir al Gobierno republicano?. En orden a las leyes, que no son fundamentales, aunque la crítica a ellas induce a su desobediencia, no es directa o indirectamente, ni por su destrucción se trastorna el Estado. Por tanto, cuando se diga contra ellas, en no pudiéndose probar que directa o inmediatamente induce a su desobediencia, debe reputarse crítica, y no merece castigo alguno. Pero si se puede probar la inducción indirecta e inmediata, corresponde la pena de la desobediencia en los términos que se ha dicho, respecto de los otros delitos. Las palabras de que se unas, el contexto, los antecedentes y consiguientes, y todas las circunstancias, serán la norma para que formen juicio los censores. Los papeles injuriosos $\mathrm{u}$ ofensivos, en los que se incluyen también los calumniosos e infamatorios, o son agentes y empleados del Gobierno, o contra los particulares. Por sentado nunca es lícito calumniar ni injuriar a nadie, y el que tal haga en un impreso deberá ser castigado conforme a las leyes. Pero aunque el publicar las faltas o defectos aún verdaderos de otros es injurioso en lo absoluto, y regularmente respecto a un particular, no lo es respecto de los funcionarios públicos, 
de garantizar la estabilidad política del régimen liberal, especialmente frente a los intentos de volver al Antiguo Régimen ${ }^{27}$. En otras palabras, el castigo de los escritos sediciosos fue un mecanismo de autoprotección del nuevo sistema político, pues los liberales fueron conscientes de su enorme debilidad política y, por ende, corrían el riesgo de que se produjeran reacciones involucionistas. En gran medida, la citada idea también se hizo presente en la inclusión y diseño del procedimiento de reforma de la Constitución de $1812^{28}$. En referencia al resto de restricciones, pretendieron proteger la moral pública, especialmente

cuyos defectos ceden en perjuicio del común, o, hablando en propiedad, no debe la injuria individual detener la publicación de lo que callando se dañaría al público. Se pueden, pues, exponer sud defectos de incapacidad y de improbidad pública, sujetándose a la prueba cuando se exija al interesado, sin tocar jamás la probidad privada o en los defectos que no dicen relación con el empleo». Véase DSCGE de 16 de marzo de 1812, pág. 2924.

La indeterminación de los impresos subversivos y el consecuente peligro de que las Juntas de Censura incurrieran en arbitrariedad a la hora de censurarlos, también preocupó al diputado Ramos de Arispe. En consecuencia propuso, entre otras cuestiones, «que el artículo 4 del mencionado decreto, en lugar de «leyes fundamentales de la Monarquía», se sustituya por «leyes que declaran y establecen la soberanía nacional, la igualdad de derechos de sus individuos, la división de poderes y la unidad de la religión católica». Véase DSCGE de 13 de febrero de 1812, págs. 2765 y ss.

27 Sobre los límites a la libertad de crítica a través de la imprenta contra las actuaciones del Gobierno o las Cortes y sus diputados, resulta de interés la lectura del escrito «sobre la libertad de escribir» publicado en el Semanario Patriótico, núm. LI, de 27 de marzo de 1811, págs. 3 y ss.

28 En este sentido, como sintetiza VARELA SUANZES-CARPEGNA, la amenaza contra la Constitución provenía «sobre todo de las fuerzas sociales perjudicadas por el nuevo orden de las cosas - la mayor parte de la Aristocracia y del Clero, y aun del mismo pueblo, cuyas elementales creencias se hallaban muy alejadas de las ideas liberales- pero también de aquellas otras insatisfechas por el mismo: las burguesías criollas». Mediante la rigidez constitucional intentaron conseguir tres cosas: «en primer lugar, evitar una prematura reforma constitucional, que obliterase la consolidación del nuevo orden y la extensión de una base social afecta al mismo (...). En segundo lugar, pretendían también evitar que una jurídicamente débil mayoría parlamentaria, y sin el debido detenimiento y circunspección, pudiese llevar a cabo la reforma constitucional, una vez que fuese jurídica lícita, cumplidos los ocho años de obligada espera (...). Por último, los diputados liberales pretendían excluir al Monarca del proceso reformista». Véase VARELA SUANZES-CARPEGNA, J.: La teoría del Estado en los orígenes del constitucionalismo hispánico (Las Cortes de Cádiz), Madrid, Centro de Estudios Constitucionales, 1983, pág. 404 y ss.

De hecho, la introducción en la Constitución de 1812 de una la cláusula de intangibilidad temporal absoluta (artículo 375) buscó que el texto constitucional se consolidase entre la opinión pública. Por su parte, la libertad de imprenta también constituía un instrumento para garantizar la propia Constitución en tanto que posibilitaba a todo español denunciar la inobservancia o infracción de la norma fundamental. Sobre ambas cuestiones, véase Semanario Patriótico núm. XCIII, de 16 de enero de 1812, pág. 163. 
la católica. En relación a esta última cuestión, el artículo 12 de la Constitución de 1812 estableció la confesionalidad del Estado ${ }^{29}$.

En lo concerniente a las sanciones, el Decreto realizó una remisión a la legislación para determinar las penas concretas, cuestión que debe ser entendida, no como una despenalización, sino como un envío al derecho entonces vigente ${ }^{30}$. Resulta de interés destacar que el artículo 9 del Decreto de 1810 previó como castigo accesorio a las sanciones previstas, la publicación de la infracción y del nombre del infractor en la Gaceta del Gobierno, con la idea de disuadir futuros abusos en materia de imprenta y, en cierta medida, contribuir a corregir el agravio realizado.

El procedimiento para la persecución de los delitos de imprenta se reguló en los artículos 15 a 17 del Decreto. En síntesis, el procedimiento se iniciaba mediante la denuncia del impreso, que correspondía en exclusiva al Poder ejecutivo o a la Administración de Justicia, esto es, las Juntas de Censura carecían de iniciativa. Posteriormente, se daba traslado del escrito a la Junta Provincial de Censura para que efectuara su calificación. En el supuesto de que se determinara que el escrito era ilícito, la autoridad judicial debía detenerlo y recoger los ejemplares distribuidos. A su vez, el autor o impresor podían solicitar copia de la calificación y contestar a la censura. En el caso de que la Junta Provincial confirmara su primera censura, el autor o el impresor podían solicitar que se trasladase el expediente a la Junta Suprema, que podía examinar la obra de nuevo hasta en dos ocasiones.

El Decreto de imprenta supuso un cambio sobresaliente en relación a la legislación precedente ${ }^{31}$. En primer lugar, la exigencia de responsabilidad a posteriori determinó la necesidad de describir en la ley, elaborada por los representantes de la Nación, los escritos que eran considerados delictivos. En segundo lugar, la nueva regulación delimitó las personas responsables de los delitos cometidos a través de la imprenta. Concretamente el Decreto estableció el principio de responsabilidad individual de los autores de los escritos y de los

29 Concretamente el artículo 12 de la Constitución de 1812 estableció lo siguiente: «La religión de la Nación española es y será perpetuamente la Católica, Apostólica, Romana, única y verdadera. La Nación la protege por leyes sabias y justas y prohíbe el ejercicio de cualquier otra». Sobre la confesionalidad del Estado, entre otros, véase FERNÁNDEZ SARASOLA, I.: La Constitución de Cádiz. Origen, contenido y proyección internacional, ob. cit., págs. 109 y ss.

30 Véase FIESTAS LOZA, A.: «La libertad de imprenta en las dos primeras etapas del liberalismo español», ob. cit., pág. 366.

31 Sobre la cuestión, véase MIRA BENAVENT, J.: Los orígenes de la libertad de expresión en España, Valencia, Tirant lo Blanch, 1995, págs. 47 y ss. 
impresores ${ }^{32}$. En tercer lugar, cambiaron los órganos encargados de conocer los abusos realizados a través de la imprenta que, en coherencia con el principio de división de poderes, debía atribuirse al poder judicial. Ahora bien, como se ha dicho, lo cierto es que el Decreto de imprenta determinó que el examen de los escritos denunciados lo debían efectuar las Juntas de Censura ${ }^{33}$. Resulta sumamente difícil determinar la naturaleza jurídica de las citadas juntas, pues en el caso de la Junta Suprema de censura era un órgano designado por el legislativo y, asimismo, debía residir cerca del Gobierno ${ }^{34}$, y las Juntas Provinciales precisaban de la colaboración del poder judicial para efectuar su función. Probablemente su naturaleza se asemeje a la de un órgano pericial, esto es, se debían limitar a calificar los escritos presentados y remitir su decisión al órgano competente de la jurisdicción ${ }^{35}$.

La aplicación práctica del Decreto de imprenta implicó numerosos recursos, consultas e incidentes ante las Cortes ${ }^{36}$, cuestión que les hizo perder mucho tiempo y esfuerzos. No obstante, la citada circunstancia hizo patente la necesi-

32 Los impresores debían poner su nombre y apellidos, y el lugar y año de impresión en todo impreso, siendo castigados por la falsedad u omisión de estos requisitos formales (art. 8). El responsable del delito era su autor, ahora bien, en el caso de que no fuera desvelada su identidad, se le impondría la misma pena que se hubiera impuesto al primero en caso de ser conocido (art. 7).

33 Concretamente, el artículo 13 del Decreto de imprenta estableció que para «asegurar la libertad de imprenta y conocer al mismo tiempo de su abuso, las Cortes nombrarán una Junta Suprema de Censura que debía residir cerca del Gobierno y estar integrada por nueve miembros y, a propuesta de éstos, «otra semejante en cada capital de provincia compuesta por cinco». Asimismo su artículo 14 determinó que tres miembros de la Junta Suprema debían ser eclesiásticos y en el caso de las Juntas Provinciales dos. La presencia del un número tan importante de eclesiásticos en las Juntas de Censura puede ser considerada como otra nueva cesión que realizó el sector liberal representado en las Cortes frente al conservador con la finalidad de que el Decreto de imprenta fuera aprobado.

34 Sobre la subordinación de las Juntas de Censura a las Cortes, véase PÉREZ JUAN, J.A.: «Los procesos de imprenta en las Cortes de Cádiz», ob.cit., pág. 231 y ss.

35 Esta también parece ser la opinión de la prensa de la época. Así, por ejemplo, El Duende publicó lo siguiente: «entre nosotros, gracias a los sabios diputados del Congreso, se declaró ya libre la imprenta, instituyéndose para el efecto unas Juntas de Censura que sirvan de peritos para calificar los escritos que se denuncien, según el reglamento aprobado por el mismo augusto Congreso». Véase El Duende núm. 2, de 2 julio de 1811, pág. 11.

36 Fueron numerosos e importantes los casos de escritos que fueron denunciados ante las Cortes, cuyo análisis excede en mucho las pretensiones del presente estudio. Sobre los mismos, entre otros, véanse ÁLVAREZ JUNCO, J. y DE LA FUENTE MONGE, G.: El nacimiento del periodismo político. La libertad de imprenta en las Cortes de Cádiz (1808-1814), ob. cit., págs. 182 y ss., FIESTAS LOZA, A.: «La libertad de imprenta en las dos primeras etapas del liberalismo español», ob. cit., págs. 375 y ss. 
dad de aprobar algunas adiciones al Decreto de Imprenta ${ }^{37}$. En referencia a las mismas, cabe destacar que se modificaron cuestiones como la composición de las Juntas de Censura, los procedimientos de censura y sus responsabilidades, etc. ${ }^{38}$.

Finalmente se reseñará que posteriormente a la aprobación del Decreto de 1810, el artículo 371 de la Constitución de 1812 elevó a rango constitucional la libertad de imprenta de la siguiente manera: «Todos los españoles tienen la libertad de escribir, imprimir y publicar sus ideas políticas sin necesidad de licencia, revisión o aprobación alguna anterior a la publicación, bajo las restricciones y la responsabilidad que establezcan las leyes ${ }^{39}{ }$. Lo cierto es que Constitución de 1812 no incluyó una parte dogmática con una declaración sistemática de derechos separada de la parte orgánica. La explicación de esta circunstancia obedece a las singularidades del proceso constituyente español, pues, entre otras razones, se quiso evitar cualquier mimetismo con la Constitución francesa que, unos años antes, había sido elaborada en el seno de la potencia invasora ${ }^{40}$. La libertad de imprenta se incluyó en el Título IX dedicado a la «instrucción pública». Ya se ha dicho que una de las principales funciones que los liberales gaditanos atribuyeron a la libertad de imprenta fue la de ilustrar al pueblo, sobre todo en las nuevas ideas revolucionarias. Ahora bien, la propagación y aceptación de las ideas liberales entre todos los sectores de la población española no quedaba garantizada exclusivamente mediante el reconocimiento de la libertad de imprenta, pues la mayoría de la población era analfabeta. El Título IX de la Constitución introdujo importantes novedades entre las que se destacará el establecimiento de un modelo educativo uniforme, universal y público que incluía la creación de las escuelas de primeras letras donde se enseñaría a los niños la escritura y el cálculo, el estudio del catecismo y una breve exposición de las obligaciones civiles (religión y liberalismo) ${ }^{41}$. Se podría decir que esta

37 Concretamente fueron el Decreto CCLXIII de las Cortes, de 10 de junio de 1813, sobre adiciones a la Ley de libertad de imprenta, el Decreto CCLXIV de las Cortes, de 10 de junio de 1813, sobre el Reglamento de las Juntas de Censura y el Decreto CCLXV de las Cortes, de 10 de junio de 1813, sobre reglas para conservar a los escritores la propiedad de sus obras.

38 Específicamente se estableció la renovación parcial cada dos años de los miembros de las Juntas de Censura; la incompatibilidad de ser miembro de las Juntas de Censura con el ejercicio de la jurisdicción civil o eclesiástica; el nombramiento de vocales suplentes para los casos de enfermedad, ausencia o inhabilitación legal, etc.

39 Obsérvese que la titularidad de la libertad de imprenta se reconoció a los españoles, término mucho más amplio que el de ciudadano. Mientras que los primeros eran titulares de los derechos civiles, los segundos también fueron titulares de los derechos políticos.

40 Sobre la cuestión, entre otros, véase FERNÁNDEZ SARASOLA, I.: La Constitución de Cádiz. Origen, contenido y proyección internacional, ob. cit., págs. 242 y ss.

41 Véanse, respectivamente, artículos 366 y 368 de la Constitución de 1812. 
medida suponía el reconocimiento de que el nuevo proyecto liberal para el país iba a tardar tiempo en aceptarse por las clases más populares. En definitiva, se trató de que los súbditos se convirtieran en ciudadanos ${ }^{42}$. Por su parte, el artículo 131.24 de la Constitución encomendó a las Cortes la garantía del ejercicio de la libertad de imprenta, esto es, las Cortes se reservaron la facultad privativa de su protección ${ }^{43}$.

\section{LA LIBERTAD DE IMPRENTA COMO PREMISA DE LA ELABORACIÓN DE LA PRIMERA CONSTITUCIÓN RACIONAL-NORMATIVA EN ESPAÑA}

Como se aludió al inicio del presente estudio, el hecho de que la libertad de imprenta se reconociera con antelación a la elaboración de la Constitución, no fue fruto de la improvisación. El texto fundamental gaditano que, como se dijo, puede calificarse como racional-normativo, debía ser precedido de todas aquellas garantías que contribuyesen a asegurar la racionalidad y la libertad en el diseño del edificio constitucional durante el proceso constituyente. Como sintetizó magistralmente GARCÍA-PELAYO, el referido concepto de Constitución «no representa una suma o resultante de decisiones parciales tomadas según van surgiendo los acontecimientos o presentándose las situaciones, sino parte de la creencia de establecer de una vez para siempre y de manera general un esquema de organización en el que se cierre toda la vida del Estado y en el que se subsuman todos los casos particulares posibles». «Se trata de una aplicación concreta (...) del concepto de ley con el que opera el liberalismo, de la creencia en la posibilidad de una planificación de la vida política, de la racionalización del acaecer político». «De la misma manera de que sólo la razón es capaz de poner orden en el caos de los fenómenos, así también sólo donde existe Constitución en sentido normativo cabe hablar de orden y estabilidad políticos ${ }^{44} »$.

42 De hecho, el artículo 25.6 de la Constitución de 1812 estableció la obligatoriedad de saber leer y escribir desde el año 30 si se quería ejercer los derechos atribuidos al ciudadano.

43 Sobre el citado precepto constitucional, el Diputado Muñoz Torrero justificó su regulación del siguiente modo: «aquí no se trata del reglamento publicado sobre la libertad política de la imprenta, que es sin duda una ley como las demás, sino de la simple protección de la misma libertad, que es un derecho de los españoles, y que como tiene por objeto servir de freno al Gobierno, debe estar a cubierto de todas las tentativas que éste pueda hacer para destruirla, y por lo mismo incumbe a las Cortes muy particularmente velar con el mayor cuidado sobre la conservación de dicha libertad». Véase DSCGE de 4 de octubre de 1811, págs. 1986 y ss.

44 Véase GARCÍA-PELAYO, M.: Derecho Constitucional comparado, ob. cit., pág. 34 y ss. 
Si una de las premisas del nuevo orden político es la racionalidad ${ }^{45}$, resultaba esencial el reconocimiento y protección de la posibilidad que ésta existiera sin cortapisas. Así, antes de elaborar la Constitución, los constituyentes debían tener la posibilidad de conocer las distintas ideas o proyectos sobre el nuevo orden político e incluso tener noticia de las ideas y reformas operadas en otros Estados $^{46}$. Por todo ello, era muy importante el reconocimiento previo de la libertad de imprenta.

Asimismo, la aspiración liberal de que la Constitución fuera la norma que regulara la vida ordinaria del Estado y, en consecuencia, fuera observada como su norma fundamental, dependía de su aceptación por parte de la Nación, especialmente al tratarse de un documento político de ruptura con el Antiguo Régimen. En este sentido, uno de los principales papeles que debía desempeñar la libertad de imprenta consistía en crear una opinión pública identificada con el pensamiento liberal y, por ende, con su proyecto constitucional. Por su parte, los absolutistas fueron conscientes de estas potencialidades ${ }^{47} \mathrm{y}$, por ello utilizaron la libertad de imprenta, que ellos mismos negaron, para lanzar sus soflamas antiliberales ${ }^{48}$ y combatir a la prensa liberal, cuestión que obligó

45 En parecido sentido, SÁNCHEZ AGESTA afirmó lo siguiente: «las Cortes se consideraban como un cuerpo constituyente que crea y define, con un plan sistemático, en un texto articulado, el orden nuevo del porvenir, cuyo único fundamento es la razón». Y, en otro momento mantuvo: «el Código constitucional (...) racionalizó la estructura política y social. La racionalizó, objetivando los principios de la revolución española. Allí estaban ordenados y declarados, encerrados en una forma jurídico política». Véase SÁNCHEZ AGESTA, L.: Historia del constitucionalismo español (1808-1936), Madrid, Centro de Estudios Constitucionales, 1984, pág. 75 y ss.

46 Sobre la influencia de las doctrinas extranjeras en el sector liberal representado en las Cortes de Cádiz, entre otros, véase FERNÁNDEZ SARASOLA, I.: La Constitución de Cádiz. Origen, contenido y proyección internacional, ob. cit., págs. 94 y ss.

47 La prensa absolutista fue impulsada y estuvo compuesta por sacerdotes y frailes que sostuvieron una abierta oposición al constitucionalismo. Sobre la prensa absolutista o servil durante el periodo de la Guerra de la Independencia, entre otros, véase CHECA GODOY, A.: La prensa española durante la Guerra de la Independencia, ob. cit., pág. 57.

48 En este sentido, como afirman ÁLVAREZ JUNCO y DE LA FUENTE, «las fuerzas anti-liberales se adaptaron bien al nuevo marco legislativo, aprovechando al máximo la libertad en él concedida, lo que les llevó a rebasar sus límites con frecuencia mayor que la de sus oponentes liberales». Concretamente, los absolutistas «levantaron la bandera patriótica en defensa de la religión y de la soberanía real para preservar los privilegios estamentales y eclesiásticos (...) alimentaron el mito de Fernando VII como rey cautivo de Napoleón y encarnación del sufrimiento de la nación española (provocado por los franceses, pero agravado, según ellos, por los liberales gaditanos), rechazaron el principio de soberanía nacional, intentaron recortar el poder de las Cortes y condenaron a la Constitución de 1812, incluida la libertad de imprenta en ella reconocida. Véase 
a las propias Cortes a intervenir directamente en varias ocasiones ${ }^{49}$. Quizá los liberales españoles sobrevaloraron las ventajas que traería para su causa el reconocimiento de la libertad de imprenta, pues el contexto social de la época, donde la mayoría de la población era analfabeta y, según los liberales, muy susceptible de ser influenciada por el clero, hacía muy difícil su tarea de instaurar una nueva legitimidad en el ejercicio del poder ${ }^{50}$. No obstante, los liberales fueron conscientes de la enorme dificultad de asentar su proyecto político revolucionario y, por ello, además de regular la obligatoriedad de las escuelas de las primeras letras donde se enseñara a los niños a leer y escribir, consideraron esencial establecer la obligatoriedad de la enseñanza del propio texto constitucional ${ }^{51}$.

Por otro lado, la elaboración de un texto constitucional racional-normativo también exigía proteger con carácter previo la libertad de discurso de los diputados frente al resto de poderes. En consecuencia, y con notable influencia del Decreto de la Asamblea Nacional Francesa, de 23 de julio de 1789, las Cortes aprobaron el Decreto I, de 24 de septiembre de 1810, donde, entre

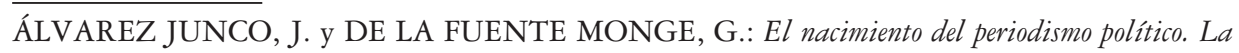
libertad de imprenta en las Cortes de Cádiz (1808-1814), ob. cit., pág. 178.

Sobre la cuestión, LA PARRA destaca que entre las publicaciones de los enemigos de las Cortes y de su proyecto de transformación del país estaban detrás magistrados, nobles y la jerarquía eclesiástica, cuestión que no sorprende dado que eran sectores tradicionalmente absolutista, lo que sorprende al citado autor es que detrás de algunas publicaciones abiertamente contrarias a las Cortes a la Regencia, máxima autoridad del régimen. Como recuerda dicho autor, «el 24 de marzo de 1813 el diputado José Zorraquín denunció ante las Cortes la sospecha de la entrega de cierta cantidad de dinero detraída de los fondos públicos al periódico ultraconservador El procurador General de la Nación y del Rey. Tras varias averiguaciones se comprobó que la regencia en 1812 asignó 4.000 reales mensuales al periódico». Véase LA PARRA LÓPEZ, E.: La libertad de prensa en las Cortes de Cádiz, ob. cit., pág. 74.

49 Un famoso ejemplo de lo citado supra se produjo como consecuencia del manifiesto que presentó a la Nación el Consejero de Estado D. Miguel de Lardizábal y Uribe, en el que se puso en entredicho la legitimidad de las propias Cortes. Sobre el citado caso, entre otros, véanse FIESTAS LOZA, A.: «La libertad de imprenta en las dos primeras etapas del liberalismo español», ob. cit., pág. 375 y ss.; Véase ÁLVAREZ JUNCO, J. y DE LA FUENTE MONGE, G.: El nacimiento del periodismo político. La libertad de imprenta en las Cortes de Cádiz (1808-1814), ob. cit., pág. 203 y ss.

50 Incluso los liberales llegaron a tener trabas provenientes de la propia Junta Suprema de Censura. En este sentido, LA PARRA acusa la Junta de efectuar censuras poco claras e incluso condescendientes con los impresos que no respetaban el texto constitucional o la tarea de las Cortes y también de retrasar la tramitación de casos de urgente solución. Véase LA PARRA LÓPEZ, E.: La libertad de prensa en las Cortes de Cádiz, ob. cit., pág. 83.

51 Sobre la instrucción pública durante el periodo estudiado, véase GARCÍA TROBAT, P.: Constitución de 1812 y educación política, Madrid, Congreso de los Diputados, 2010, págs. 375 y ss. 
otras cuestiones, reconocieron la inviolabilidad parlamentaria del siguiente modo: «las Cortes Generales y extraordinarias declaran que las personas de los diputados son inviolables, y que no se pueda intentar por ninguna autoridad ni persona particular cosa alguna con los diputados, sino en los términos que se establezcan en el reglamento general ${ }^{52}$ ». La citada inviolabilidad pretendió asegurar la libre formación de la voluntad de las Cortes que, según las coordenadas ideológicas liberales, constituían el núcleo central del nuevo modelo político. La inviolabilidad parlamentaria implicaba que no se podía iniciar ningún tipo de procedimiento en ningún tiempo, por parte de ninguna autoridad, por motivo de las opiniones y los dictámenes emitidos por los diputados durante las sesiones parlamentarias ${ }^{53}$. Desde los planteamientos del parlamentarismo liberal, mediante la libre y pública discusión se alcanza la verdad más segura, es decir, la verdad se genera a partir de la libre concurrencia de opiniones. Por ello, era de vital importancia asegurar que las opiniones de los representantes de la Nación fueran expresadas con total libertad y, a su vez, pudieran ser escuchadas por los demás diputados antes de adoptar cualquier tipo de decisión que afectara a la elaboración de la norma fundamental del Estado ${ }^{54}$.

52 Posteriormente el artículo 4 (Cap. IV) del Reglamento para el Gobierno de Interior de las Cortes, de 27 de noviembre de 1810, estableció que: «Las personas de los Diputados son inviolables, y no podrá intentarse contra ellos acción, demanda ni procedimiento alguno en ningún tiempo y por ninguna autoridad, de cualquier clase que sea, por sus opiniones y dictámenes». Asimismo téngase en cuenta que mediante el Decreto XIII, de 28 de noviembre de 1810, se confirmó la inviolabilidad de los Diputados y establecieron los términos en que responderían civil o penalmente los Diputados. Por último, el artículo 128 de la Constitución de 1812 elevó a rango constitucional la inviolabilidad de los diputados del siguiente modo: «Los diputados serán inviolables por sus opiniones, y en ningún tiempo ni caso, ni por ninguna autoridad, podrán ser reconvenidos por ellas». Sobre las reglas de funcionamiento y la estructura administrativa y de servicios durante las Cortes de Cádiz, véase DE DIEGO GARCÍA, E.: «La «Orgánica» de las Cortes», Cuadernos de Historia Contemporánea», Vol. 24, 2002, págs. 23 y ss.

53 Durante la tramitación del proyecto de Constitución se discutió sobre el alcance de la inviolabilidad, pues el Diputado Simón consideró que la inviolabilidad debía circunscribirse a las ideas políticas y no a las religiosas, cuestión que recuerda al Decreto de imprenta. Como se dijo en otro momento, resulta muy difícil deslindar completamente ambas cuestiones. Al respecto, el Diputado Argüelles recordó la complejidad de deslindar las opiniones políticas de las religiosas, pues el mismo había sido acusado de hereje en algunos papales públicos por proponer que parte de los diezmos podrían aplicarse a las necesidades de la Patria. En sentido similar, Capmany recordó que hace mucho tiempo se consideraba que tocar a un eclesiástico es tocar a la Iglesia, cuestión que está expuesta a mil interpretaciones. Véase DSCGE de 1 de octubre de 1811, págs. 1967 y ss.

54 El reconocimiento de la inviolabilidad parlamentaria no es óbice para que existieran mecanismos disciplinarios para asegurar la corrección de los Diputados en sus discursos. Así, el 


\section{LA LIBERTAD DE IMPRENTA COMO PIEZA CLAVE DE LAS RECIÉN CREADAS INSTITUCIONES LIBERALES}

La lógica sintetizada en el epígrafe precedente no sólo se refiere al proceso constituyente, sino que, además, debía operar continuamente en la obra y trabajos de los poderes constituidos. En este sentido, la ley, obra del legislador, también debía contar con la guía y censura de la opinión pública, en el sentido de que los representantes de la Nación debían conocer las opiniones de los españoles. En referencia al Gobierno, pero también se puede extender a todos los poderes públicos ${ }^{55}$, la libertad de imprenta constituiría un importante instrumento de lucha contra la arbitrariedad ${ }^{56}$. Asimismo se trata de una fórmula que teóricamente permitiría a las Cortes asegurar la eficacia de sus disposiciones normativas, pues gracias a la nueva legitimidad política y la guía de la opinión pública, su cumplimiento no residiría en la coacción del Estado, sino en su acatamiento voluntario por ser consideradas legítimas.

La libertad de imprenta fue una pieza esencial, pero no exclusiva, para el funcionamiento del nuevo sistema liberal, pues para desarrollar completamente sus potencialidades necesitó de otras instituciones complementarias como la publicidad parlamentaria ${ }^{57}$. Pues bien, durante el proceso constituyente

artículo 9 (Cap. II) del Reglamento para el Gobierno de Interior de las Cortes, de 27 de noviembre de 1810, estableció que «si el Presidente impusiere silencio a algún Diputado, o le mandase guardar moderación primera, segunda y tercera vez, y no fuere obedecido, podrá ordenarle que salga de la Sala durante aquella sesión; lo que obedecerá el Diputado sin contradicción».

55 «En una monarquía moderada, además de los tres poderes legislativo, ejecutivo, y judiciario, es indispensable que haya otro inherente al pueblo que sirva de freno a aquellos tres». Véase El Duende núm. 2, de 2 julio de 1811, pág. 9.

$56 \mathrm{Al}$ respecto, como acertadamente matiza FERNÁNDEZ SARASOLA, la opinión pública actuaba de manera distinta en relación al Gobierno y las Cortes. Concretamente, en referencia al primero, la opinión pública actuaba de una manera unidireccional y negativa, esto es, a modo de censura pública. En referencia al legislativo, la opinión pública actuaba de modo bidireccional y positivo, pues además de ejercer la función de censura pública, también ejercía la función positiva de guía. Véase FERNÁNDEZ SARASOLA, I.: «La opinión pública. De la ilustración a las Cortes de Cádiz», Ayer, núm. 80, 2010, págs. 68 y ss.

57 En este sentido, el diputado Muñoz Torrero, durante la sesión en la que varios diputados abogaron por la necesidad de abordar rápidamente el estudio del Decreto de Imprenta, consideró que «había que seguir un rumbo opuesto al de la Junta Central, sustituyendo a su criminal silencio y misteriosa conducta la publicidad de las sesiones y la libertad de escribir sobre asuntos políticos». Véase El Conciso, núm. XX, 30 de septiembre de 1810, pág. 95. Por su parte, el diputado Luxán, durante la tramitación del Decreto de Imprenta, afirmó que le habían encargado sus comitentes la publicidad de las sesiones parlamentarias y la libertad de imprenta. Véase El Conciso, núm. XXIX, 18 de octubre de 1810, pág. 135. De ambos testimonios se deduce que se trata de dos cuestiones íntimamente ligadas para la construcción del nuevo sistema liberal. 
gaditano existían dos concepciones claramente opuestas sobre la citada institución. De un lado, el modelo inglés, donde las deliberaciones y votaciones eran secretas, lo que implicaba que estaba vedada la presencia de público en las sesiones parlamentarias y prohibida la publicación de los debates sin la debida autorización de la cámara. El fundamento de esta restricción consistió en asegurar la independencia y libertad de las Cámaras frente a las injerencias del Monarca o las eventuales presiones de las masas. No obstante, esta práctica fue paulatinamente abandonada, debido a las exigencias sociales y a la evolución de las prácticas políticas ${ }^{58}$. De otro lado, el modelo francés, cuya Constitución de 1791 estableció que «las deliberaciones del cuerpo legislativo serán públicas y las actas de sus sesiones serán impresas». Este segundo modelo fue el adoptado en el constitucionalismo europeo continental posterior a la revolución francesa, y el caso español, en esencia, no fue una excepción. Así, en referencia al periodo constituyente gaditano, el artículo 3 del Capítulo I del Reglamento para el Gobierno Interior de las Cortes, de 27 de noviembre de 1810, estableció que exclusivamente los hombres podían asistir a las sesiones públicas ${ }^{59}$. Como se infiere, la posibilidad de que el público asistiera a las sesiones parlamentarias

58 Sobre la cuestión, entre otros, véanse DE VEGA GARCÍA, P.: «El principio de publicidad parlamentaria y su proyección constitucional», Revista de Estudios Políticos, núm. 43, 1985, pág. 46, JUNCO, J. y DE LA FUENTE MONGE, G.: El nacimiento del periodismo político. La libertad de imprenta en las Cortes de Cádiz (1808-1814), ob. cit., pág. 83.

59 Concretamente, el referido artículo 3 (Cap. I) estableció que: «no se permitirá a las mujeres la entrada en ninguna de las galerías de la sala de sesiones. Los hombres de todas las clases podrán indistintamente asistir a ellas, quedando libre, y a disposición del cuerpo diplomático extranjero, y de los Generales en Jefe de los ejércitos de las naciones aliadas y los de España, la primera división de la galería baja a la derecha del dosel». Lo cierto es que la cuestión de la asistencia del público ya había sido acordada previamente con carácter provisional, pues como consta en el acta de la sesión secreta de las Cortes Generales, de 26 de septiembre de 1810, se acordó, entre otras cuestiones, que se negara la entrada a las mujeres, que en las galerías se admitieran hombres de toda condición y que el uso de la primera división de la galería quedara al uso del cuerpo diplomático extranjero. Véase ASSCGE de 26 de septiembre de 1810. Posteriormente, el artículo 126 de la Constitución elevó a rango constitucional el principio de publicidad de las sesiones parlamentarias del siguiente modo: «Las sesiones de las Cortes serán públicas, y sólo en casos que exijan reserva podrán celebrarse sesiones secretas». Durante la discusión del citado precepto, varios diputados como, por ejemplo, Argüelles o Capmany, coincidieron en que los asuntos a discutir en secreto serían pocos, lo cual puede ser considerado paradójico, teniendo en cuenta los antecedentes. Véase DSCGE de 1 de octubre de 1811, págs. 1966 y ss.

El público asistente a las sesiones parlamentarias públicas, como recogen las crónicas periodísticas de la época, participó activamente en los debates parlamentarios mostrando su aprobación o desaprobación sobre los discursos de los Diputados. Así, por ejemplo, después de que el Diputado Morales Gallego afirmara que la «libertad de imprenta era para él un crimen, es antisocial, antipolítica, antipatriótica», como recogió la prensa de la época, «el pueblo estuvo a pique de 
implicó el acceso de la prensa, muy politizada en la época, que puede ser considerada como un intermediario cualificado entre las Cortes y los ciudadanos ${ }^{60}$. No obstante, si bien la regla general fue la publicidad de las sesiones, lo cierto es que también se contempló la posibilidad de realizar sesiones secretas si así lo decidían expresamente las propias Cortes en uno de los siguientes supuestos: a petición del Consejo de la Regencia; a petición de algún Diputado, aceptada por la propia cámara; en caso de que se formularan quejas o acusaciones contra los miembros del Consejo de la Regencia o los Diputados; y en el caso de que el público asistente no guardara el silencio debido ${ }^{61}$. Asimismo se dispuso la necesidad de que los Diputados juraran guardar silencio sobre lo sucedido en las sesiones secretas ${ }^{62}$. El excesivo recurso a las sesiones secretas fue criticado por algún diputado y por la prensa de la época, pues en gran medida suponía una contradicción con los postulados e intereses liberales, y podía generar sospechas entre la población sobre los verdaderos motivos de actuación de las Cortes ${ }^{63}$.

perder su moderación, lo que produjo quejas de parte de algunos señores diputados». Véase El Conciso, núm. XXX, de 20 de octubre de 1810, págs. 138 y ss.

60 Como recuerdan ÁLVAREZ JUNCO y DE LA FUENTE, «los periodistas políticos, eran también los primeros en poder formarse una opinión sobre los debates y acuerdos de las Cortes e, igualmente, los únicos - descontados los diputados- que podían encargarse de difundir entre el resto de la sociedad esa información política, junto a unas primeras valoraciones, a través de los periódicos u otros medios de comunicación de menor alcance». ÁLVAREZ JUNCO, J. y DE LA FUENTE MONGE, G.: El nacimiento del periodismo político. La libertad de imprenta en las Cortes de Cádiz (1808-1814), ob. cit., pág. 86.

${ }^{61}$ Véanse artículo 9 y siguientes del Capítulo I del Reglamento para el Gobierno Interior de las Cortes, de 27 de noviembre de 1810. Sobre la cuestión, MARCUELLO BENEDICTO afirma que «la apuesta por la publicidad debe, sin embargo, matizarse, pues en la práctica las Cortes Generales y Extraordinarias arrojan como balance 817 sesiones secretas frente a 996 de carácter público». Véase MARCUELLO BENEDICTO, J.I.: «Las Cortes Generales y extraordinarias: organización y poderes para un gobierno de Asamblea», Ayer, núm. 1, 1991, pág. 78.

62 La introducción del juramento de guardar secreto sobre las sesiones o materias reservadas se acordó al poco tiempo de iniciarse las reuniones de las Cortes. Véase ASSCGE de 25 de septiembre de 1810. Posteriormente, el artículo 1 (Cap. I) del Reglamento para el Gobierno Interior de las Cortes de 27 de noviembre de 1810, incluyó en la formula de prestar juramento lo siguiente: « ¿juráis guardar secreto en todos aquellos casos en los que las Cortes manden observarlo?.

No obstante, lo cierto es que resultaba sumamente dificultoso asegurar el cumplimiento del deber de secreto, pues como se afirmó en el Semanario Patriótico, «¿cómo es posible que los negocios y disputas entre ciento y cincuenta hombres puedan permanecer ocultas, por más sigilo que quieran guardar y por más puertas que se cierren?». Véase Semanario Patriótico, núm. LXXXIII, de 7 de noviembre de 1811, pág. 365.

63 En referencia al secreto de las sesiones parlamentarias, el Semanario Patriótico tras recordar que «en la publicidad de las deliberaciones reconocisteis el derecho sagrado que tiene la nación de inspeccionar vuestra conducta en el manejo de sus intereses.» Y que «en la libertad de 
También se estableció, como norma general, la publicidad de las votaciones parlamentarias. Concretamente, el Reglamento para el Gobierno Interior de las Cortes, de 27 de septiembre de 1810, estableció que el sistema de votación ordinario consistía en la votación por acto de levantarse ${ }^{64} \mathrm{o}$, en los asuntos con cierta importancia, por la expresión individual del sí o el no ${ }^{65}$. Como excepción, se reguló la posibilidad de realizar votaciones secretas acudiendo al sistema del escrutinio para «las votaciones de elecciones y nombramientos de todas las clases para dentro y fuera del Congreso ${ }^{66}{ }_{»}$. No obstante, el artículo 10 (Cap. VI) del citado reglamento, amplió la posibilidad del voto por escrutinio al afirmar lo siguiente: «fuera de los casos expresados en los artículos anteriores no podrá usarse del escrutinio, que por su naturaleza es secreto, a no ser que el Congreso en otros casos y con previa discusión lo acuerde». La publicidad del voto no resultaba una cuestión baladí. El hecho que de la Nación entera pudiera conocer el voto de cada uno de sus representantes podía influir en el sentido del mismo. Así, por ejemplo, conscientes de esta idea, varios diputados discutieron sobre el sistema de votación a utilizar para la aprobación o rechazo del Decreto de imprenta ${ }^{67}$.

imprenta le disteis el mejor medios para conocerlos», criticó con dureza el recurso de las Cortes a las sesiones secretas entre otros, mediante los siguientes argumentos: «¿qué quieren decir esas sesiones secretas que se repiten todos los días como si fueran una regla inviolable de vuestro instituto?. Son por ventura tantos los negocios del poder legislativo que exigen secreto en su deliberación?. Dejad la reserva para los gabinetes de Estado o para los Consejos militares (...) ¿Pero, vosotros?. Vosotros no estáis en ese caso; y si seguís como hasta ahora, es fuerza dar razón a los que dicen que faltáis a vuestro deber y vuestros principios, ocultando al publico vuestras deliberaciones que debe oír». Véase Semanario Patriótico núm. XXXV, de 6 de diciembre de 1810, págs. 51 y ss. En parecido sentido, también véase Semanario Patriótico núm. LXXVI, de 19 de septiembre de 1811, págs. 208 y ss.

64 Concretamente el artículo 11 (Cap. VI) del Reglamento para el Gobierno Interior de las Cortes de 27 de noviembre de 1810, estableció que: «La votación por el acto de levantarse los que estén por la afirmativa; se usará generalmente en asuntos triviales; y aún en los de importancia, siempre que la opinión general se vea muy inclinada a uno de los extremos».

65 Así, en el artículo 13 (Cap. VI) del citado Reglamento estableció: "por la expresión individual del Sí y el No se harán las votaciones de los asuntos que, no perteneciendo al escrutinio, se gradúen de importancia; pero como en estos casos no pueden expresarse en un reglamento, los acordarán las Cortes cuando ocurran, y cualquier diputado tendrá derecho a pedirlo».

66 Véase artículos 5 y siguientes del citado Reglamento.

67 Sobre la cuestión aludida supra, El Conciso publicó lo siguiente: «se trató después si la votación debía ser en público o en secreto; hubo diversos pareceres; y aunque el Sr. Argüelles fue del dictamen de que se votase en la forma ordinaria de levantarse los que la aprobasen, algunos diputados expusieron que debía hacerse en secreto para que hubiese más libertad. Sobre esto hubo algunos debates; y aunque se valían de todos los medios para sostener esta opinión, sin embargo se levantó el Sr. Luxan y dijo que la nación española quería que todos fuesen héroes; que no sólo 
Asimismo, la publicidad parlamentaria tuvo su traducción en la publicación del Diario de Sesiones donde se recogían las deliberaciones y votaciones de las Cortes ${ }^{68}$. Concretamente, el 5 de octubre de 1810 se votó la creación del periódico de las Cortes ${ }^{69}$. Al respecto, se vuelve a observar la misma lógica, la publicidad parlamentaria posibilitaba que los representados conocieran las posturas de sus representantes en los distintos asuntos de la vida del Estado y, por tanto, facilitaba su elección y fiscalización con mayor rigor ${ }^{70}$. De la misma manera, dado que los diputados constituían una selecta extracción de la pobla-

la firmeza y la constancia en los que estaban a favor de la libertad de imprenta, sino en los que estaban contra esta misma libertad; y que la nación miraría con el mismo semblante a los que heroicamente sostuvieron en el voto la misma firmeza y principio a favor del proyecto, manifiestos en sus discursos cuando combatían la opinión contraria, que aquellos con virtud y constancia diesen el voto contra la libertad de la imprenta, pues unos y otros obraban con igual heroicidad y eran iguales a sus ojos. Se procedió a votar sobre esto, y casi por unanimidad se determinó que la votación fuese en público» En consecuencia, la votación del proyecto de imprenta se hizo pública y nominal. Véase El Conciso, núm. XXXII, de 24 de octubre de 1810, págs. 145 y ss. Sobre la aludida cuestión, véase también Semanario Patriótico, núm. XXXIV, de 29 de noviembre de 1810, págs. 45 y ss.

68 Concretamente, la primera sesión parlamentaria que se reprodujo en el Diario de Cortes fue la celebrada el 16 de diciembre de 1810. Las actas publicadas precedentemente sólo recogieron un breve resumen de los acuerdos tomados y de los asuntos discutidos. Sobre los debates y puesta en funcionamiento del Diario de sesiones de las Cortes, véase FIESTAS LOZA, A.: «El Diario de Sesiones de las Cortes (1810-1814)», Anuario de Historia del Derecho español, núm. 65, 1995, págs. 533 y ss.

69 En torno a su creación, resulta interesante señalar que su fundamento no sólo reside en crear un instrumento de publicidad de la obra y actuación de las Cortes, sino que también se justifica en el principio de división de poderes. Como afirman ÁLVAREZ JUNCO y DE LA FUENTE, «los diputados detectaron una cierta falta de interés por parte del Consejo de la Regencia a la hora de promulgar con diligencia en la Gaceta oficial los Decretos de las Cortes. (...) con la creación de su diario las Cortes se garantizaban un medio de comunicación propio e independiente que les servía tanto para agilizar las labores parlamentarias como para dar a los ciudadanos una información puntual, detallada y exacta de sus trabajos y acuerdos». Véase ÁLVAREZ JUNCO, J. y DE LA FUENTE MONGE, G.: El nacimiento del periodismo político. La libertad de imprenta en las Cortes de Cádiz (1808-1814), ob. cit., pág. 89.

70 En este sentido, Argüelles sintetizó la importancia de la creación del Diario de Sesiones por parte de las Cortes de la siguiente manera: «Cada uno de nosotros desempeña su cargo con exponer libremente su opinión, y sostenerla en el modo que le es posible, bajo las reglas establecidas en las Cortes y que prescribe la buena educación y la cordialidad. El Congreso deliberará en público; sus individuos serán juzgados por la opinión pública conforme a su conducta durante su permanencia en él. La posterioridad podrá recurrir a las Actas y documentos en que se halla consignada la opinión de cada uno si le interesase por casualidad, o por otro motivo, calificar aisladamente a los individuos, aproximando los hechos, comparando los dictámenes y principios en la serie de su diputación respectiva». Véase DSCGE, de 15 de julio de 1811, pág. 1452. 
ción, mediante el conocimiento de sus opiniones y actuaciones se propiciaba la ilustración de la población y, por extensión, su adhesión al nuevo proyecto constitucional $^{71}$. Otro objetivo de la publicación del Diario de Sesiones fue la idea de evitar intermediarios entre las Cortes y los ciudadanos. Al respecto, téngase en cuenta que el acceso de los periodistas a las sesiones de las Cortes originó el denominado periodismo parlamentario y, por ende, surgieron las primeras fricciones con los representantes de la Nación. En alguna ocasión se hizo mención en sede parlamentaria al poco decoro con el que se trataba a los diputados en las crónicas parlamentarias y a las inexactitudes que contenía la prensa $^{72}$, en otras se acusó directamente a la prensa de injuriar a los diputados como consecuencia de tergiversar lo dicho durante los debates parlamentarios ${ }^{73}$.

71 Lo cierto, es que esta idea también estuvo en el bando servil o absolutista, llegando a denunciar que los resúmenes de las intervenciones estaban escorados hacia el sector liberal, lo que según la doctrina parece no corresponderse con la realidad. Véase CHECA GODOY, A.: La prensa española durante la Guerra de la Independencia, ob. cit. pág. 100.

Sobre el grado de exactitud con el que el Diario de Sesiones reflejó lo acontecido en las Cortes, FIESTAS LOZAS concluye lo siguiente: «El Diario de Sesiones (y, a mi entender, el principal problema que plantea) no refleja con fidelidad lo que se dijo o trató en el Congreso durante el periodo gaditano ya que las Cortes, adoptando una actitud censora, sólo permitieron que se consignara en el mismo «aquello que no conviene omitir». Véase FIESTAS LOZA, A.: «El Diario de Sesiones de las Cortes (1810-1814)», ob. cit., pág. 557. Lo cierto es que la misma idea se puede afirmar en relación a la prensa presente en las galerías de las Cortes. Como afirma DURÁN LÓPEZ, todos los periódicos que enviaban cronistas a las galerías para asistir a las reuniones sometían sus resúmenes a las mismas o similares manipulaciones que el citado Diario de Sesiones como, por ejemplo, «retrasos, cortes, manipulaciones técnicas, otras interesadas políticamente, extractos, resúmenes, escasa literalidad de los pasajes entrecomillados». Véase DURÁN LÓPEZ, F. (Ed.): Crónicas de Cortes del Semanario Patriótico. 1810-1812, Cádiz, Ayuntamiento de Cádiz, 2003, pág. 18.

72 A modo de ejemplo, véanse El Conciso, núm. XXIV, de 8 de octubre de 1810, pág. 113 y ss y núm. XXV, de 10 de octubre, pág. 117; Semanario Patriótico, núm. XLVI, 21 de febrero de 1811 , pág. 341.

73 A modo de ejemplo cabe citar el caso del diputado Villanueva, hecho que ocurrió antes de que estuviera aprobado el Decreto de libertad de imprenta. Concretamente el Conciso publicó en su núm. XXXIV, de 6 de noviembre de 1810, que el citado diputado «leyó un discurso piadoso; no se entendió muy bien el final, pero según noticias y la caridad del orador, es de creer que cediese sus rentas en beneficio de la patria, reservándose lo preciso únicamente para su alimento», cuestión que según el citado Diputado no se correspondía con la realidad. El asunto fue llevado a las Cortes por el Sr. Mazarrasa considerándolo como atentatorio contra la inviolabilidad de las Cortes. En el debate sobre la cuestión un diputado entendió, probablemente a los efectos de evitar cualquier eventual malentendido, que se hacía necesario el periódico de Cortes, a lo que fue contestado por el Diputado Oliveros que ya se estaba formado un plan. Véase El Conciso, núm. XLII, de 10 de noviembre, de 1810, pág. 203. 
Asimismo, se denunció la parcialidad en las crónicas parlamentarias ${ }^{74}$. Lo cierto es que el citado objetivo no se alcanzó, pues los periódicos de la época, si bien eran menos neutrales que la publicación oficial, pues en su gran mayoría tenían una clara tendencia en sentido liberal o servil, transmitían su información de una manera más rápida, eficaz y amena que la recogida en la publicación oficial de las Cortes ${ }^{75}$.

\section{BIBLIOGRAFÍA CITADA}

ALMUIÑA, C., «Opinión pública y revolución liberal», Cuadernos de Historia Contemporánea, vol. XXIV, 2002, págs. 81 y ss.

ÁLVAREZ CORA, E., «Libertad, abuso y delito de imprenta en las Cortes de Cádiz», Anuario de Historia del Derecho español, tomo LXXXI, 2011, págs. 493 y ss.

ÁLVAREZ JUNCO, J. y DE LA FUENTE MONGE, G., El nacimiento del periodismo político. La libertad de imprenta en las Cortes de Cádiz (1808-1814), Madrid, Ediciones APM, 2009.

ARGÜELLES, A., Examen bistórico de la reforma de la Constitución española, Bilbao, Junta General del Principado de Asturias, 2002.

ARTOLA GALLEGO, M., Los orígenes de la España contemporánea, Madrid, Instituto de Estudios Políticos, vol. I, 1978.

CASTRO ALFÍN, D., Los males de la imprenta. Política y libertad de prensa en una sociedad dual, Madrid, CIS, 1998.

CHECA GODOY, A., La prensa española durante la Guerra de la Independencia, Cádiz, Quórum editores, 2009.

CRUZ SEOANE, M., «Periodismo y Cortes» en ESCUDERO J.A. (Dir.), Cortes y Constitución de Cádiz, vol. II, Madrid, Espasa, 2011, págs. 154 y ss.

DE DIEGO GARCÍA, E., «La «Orgánica» de las Cortes», Cuadernos de Historia Contemporánea», vol. 24, 2002, págs. 23 y ss.

DE VEGA GARCÍA, P., «El principio de publicidad parlamentaria y su proyección constitucional», Revista de Estudios Políticos, núm. 43, 1985, págs. 45 y ss.

74 Sobre la cuestión, véase CRUZ SEONANE, M.: «Periodismo y Cortes», en ESCUDERO J.A. (Dir.): Cortes y Constitución de Cádiz, ob.cit., pág. 160 y ss.

75 El retraso en la elaboración y distribución del Diario de Sesiones se debió a multitud de factores. Así, por ejemplo, el diputado Capmany, miembro de la Comisión del periódico de Cortes, denunció que las peticiones de los diputados de «que se impriman cuanto dicen y cuanto leen, y al tratarse en el Congreso de mil cosas peculiares a los tribunales de justicia, hacían que el periódico saliese con más retraso cada vez, por falta de letra y operarios». Por ello, propuso que «se estableciese una comisión de concisión de las discusiones, para que no abultasen tanto impresas». Véase Semanario Patriótico, núm. XLIII, de 31 de enero, de 1811, pág. 257. 
DURÁn LÓPEZ, F. (Ed.), Crónicas de Cortes del Semanario Patriótico. 1810-1812, Cádiz, Ayuntamiento de Cádiz, 2003.

ESCUDERO, J.A., «Las Cortes de Cádiz y la supresión de la Inquisición», en ESCUDERO J.A. (Dir.), Cortes y Constitución de Cádiz, vol. II, Madrid, Espasa, 2011, págs. 285 y ss.

FERNÁNDEZ SARASOLA, I., La Constitución de Cádiz. Origen, contenido y proyección internacional, Madrid, CEPC, 2011.

— «La opinión pública. De la ilustración a las Cortes de Cádiz, Ayer, núm. 80, 2010, págs. 53 y ss.

— «Opinión pública y "libertades de expresión” en el constitucionalismo español», Historia Constitucional (revista electrónica), núm. 7, 2006, págs. 159 y ss.

- Poder y libertad: los orígenes de la responsabilidad del ejecutivo en España (1808-1823), Madrid, CEPC, 2001.

FERNANDEZ SEGADO, F., «La libertad de imprenta en las Cortes de Cádiz», Revista de Estudios Políticos, núm. 124, 2004, págs. 29 y ss.

FIESTAS LOZA, A., «La libertad de imprenta en las dos primeras etapas del liberalismo español», Anuario de Historia del Derecho español, tomo LIX, 1989, págs. 351 y ss.

— «El Diario de Sesiones de las Cortes (1810-1814)», Anuario de Historia del Derecho español, núm. 65, 1995, págs. 533 y ss.

FLOREZ ESTRADA, A., En defensa de las Cortes, Madrid, Ciencia Nueva, 1967.

GARCÍA TROBAT, P., Constitución de 1812 y educación política, Madrid, Congreso de los Diputados, 2010.

GARCÍA-PELAYO, M., Derecho Constitucional comparado, Madrid, Alianza, 1999.

GIL NOVALES, A., Prensa, guerra y revolución. Los periódicos españoles durante la Guerra de la Independencia, Madrid, CESIC, 2009.

GÓMEZ-REINO Y CARNOTA, E., Aproximación histórica al derecho de la imprenta y de la prensa (1480-1966), Madrid, Instituto de Estudios Administrativos, 1977.

LA PARRA LÓPEZ, E., La libertad de prensa en las Cortes de Cádiz, Valencia, Nau Llibres, 1984.

MARCUELLO BENEDICTO, J.I., «Las Cortes Generales y extraordinarias: organización y poderes para un gobierno de Asamblea», Ayer, núm. 1, 1991, págs. 67 y ss.

— «La libertad de imprenta y su marco legal en la España liberal», Ayer, núm. 34, 1999, págs. 65 y ss.

MIRA BENAVENT, J., Los orígenes de la libertad de expresión en España, Valencia, Tirant lo Blanch, 1995.

PÉREZ JUAN, J.A., «Los procesos de imprenta en las Cortes de Cádiz», en ESCUDERO J.A. (Dir.), Cortes y Constitución de Cádiz, vol. II, Madrid, Espasa, 2011, págs. 230 y ss. 
PIZARROSO QUINTERO, A., «Prensa y propaganda bélica 1808-1814», Cuadernos dieciochistas, núm. 8, 2007, págs. 203 y ss.

SÁNCHEZ AGESTA, L., Historia del constitucionalismo español (1808-1936), Madrid, Centro de Estudios Constitucionales, 1984.

VARELA SUANZES-CARPEGNA, J., La teoría del Estado en los orígenes del constitucionalismo hispánico (Las Cortes de Cádiz), Madrid, Centro de Estudios Constitucionales, 1983.

Title:

FREEDOM OF THE PRESS WITHIN THE CONSTITUTIONAL DESIGN OF THE CADIZ COURTS

\section{Summary:}

1. The context within the recognition of Freedom of the press. 2. The basics of Freedom of the press 3. Contents and limits of Freedom of the press. 4. The Freedom of the press as a premise in the elaboration of the first rational-regulatory Constitution in Spain. 5. Freedom of the press as a key component of the recently created liberal institutions.

\section{Resumen:}

La presente aportación estudia el papel que desempeñó la libertad de imprenta durante la primera experiencia constitucional en España. En el examen del contexto de su reconocimiento se observa que la libertad de imprenta se alcanzó antes de facto que de iure, circunstancia que facilitó enormemente la libre circulación de todo tipo de escritos y que, asimismo, coadyuvó al intercambio de ideas sobre el nuevo modelo de Estado. Del estudio de las principales razones que motivaron la aprobación del Decreto de imprenta de 1810 se desprende que las Cortes no concibieron la libertad de imprenta exclusivamente como un derecho individual que posibilitaba el libre desarrollo de la personalidad sino que, además, se trataba de un derecho llamado a desempeñar importantes funciones en el nuevo modelo político que deseaban implantar. Idea que corrobora el análisis del proceso constituyente y del funcionamiento de las instituciones creadas por la Constitución de 1812. Concretamente, en referencia al proceso constituyente, se observa que con carácter previo a la aprobación de una Constitución digna de ser calificada como racional-normativa, fue imprescindible reconocer y garantizar la libertad de imprenta. Y, en relación al funcionamiento de las nuevas instituciones liberales, la citada libertad pública era del todo necesaria, dado que, entre otras cuestiones, posibilitó a los españoles fiscalizar y controlar el ejercicio del poder político. 


\section{Summary:}

Present contribution studies the role that freedom of the press fulfilled during the first constitutional experience in Spain. Within the study of the context of its recognition it is observed that Freedom of the press was achieved before de facto rather than de iure. This circumstance made possible the circulation of all kind of documents which also contributed to the exchange of ideas about the new State model. From the study of the main reasons that motivated the approval of the Press Decree of 1810 can be inferred that Courts did not only conceive Freedom of the press as a mere individual right that enabled the free development of personality, but also as a right that was expected to fulfill important functions in the new political model that was intended to be established. This idea is corroborated by the analysis of the constituent process and the work environment of the institutions created in the 1812 Constitution. With reference to the constituent process, it is observed that previous to the approval of a Constitution that could be called as rational- regulatory, it was compulsory to recognize and guarantee the Freedom of the press. Finally, and related to the work environment of the new liberal institutions, the aforementioned public liberty was entirely necessary as it allowed the citizens the supervision and control of the political power's exercise among other issues.

\section{Palabras clave:}

Libertad de imprenta, Constitución de 1812, Cortes de Cádiz, Constitución racional-normativa.

\section{Key words:}

Freedom of the press Constitution of 1812, Courts of Cadiz, Constitution rational-regulatory. 